\title{
高温·高压下の有機溶媒中におけるチタンアルコキシドとリン酸エステルの 共熱分解による耐熱性リン修飾酸化チタンナノ結晶の合成
}

\author{
河野将明·古島利美·古南 博 ·香川公司* 計良善也 \\ 近畿大学理工学部応用化学科, 577-8502 東大阪市小若江 3-4-1 \\ *関西電力(株)総合技術研究所, 661-0974 尼崎市若王子 3-11-20
}

\section{Synthesis of Thermally Stable, Phosphorus-Modified Titanium Oxide Nano-Crystals by Thermal Decomposition of Titanium Alkoxide and Phosphoric Ester in Organic Solvent of High Temperature and High Pressure}

\author{
Masaaki KOHNO, Toshimi FURUSHIMA, Hiroshi KOMINAMI, Koji KAGAWA* and Yoshiya KERA \\ Department of Applied Chemistry, Faculty of Science and Engineering, Kinki University, \\ Kowakae, Higashi-Osaka-shi, Osaka 577-8502 \\ *Technical Research Center, The Kansai Electric Power Co., Inc., Nakoji, Amagasaki-shi, Hyogo 661-0974
}

\begin{abstract}
Phosphorous-modified titanium oxide $\left(\mathrm{P}-\mathrm{TiO}_{2}{ }^{\prime} \mathrm{s}\right)$ nano-crystals in anatase form were synthesized by thermal decomposition of mixtures of titanium(IV) isopropoxide and ethyl phosphate in toluene in autoclave at $300^{\circ} \mathrm{C}$. These $\mathrm{P}-\mathrm{TiO}_{2}$ 's had high rutile-transformation temperatures and maintained large specific surface areas even at elevated temperatures $\left(550-800^{\circ} \mathrm{C}\right)$. For example, the product prepared from a mixture of Ti/ $\mathbb{P}$ molar ratio of 19 transformed into rutile at around $1000^{\circ} \mathrm{C}$, and it possessed a specific surface area of $54 \mathrm{~m}^{2}$. $\mathrm{g}^{-1}$, even after calcination at $800^{\circ} \mathrm{C}$ for $1 \mathrm{~h}$

[Received October 2, 2000; Accepted December 11, 2000]
\end{abstract}

Key-words : Titanium oxide, Anatase, Rutile, Thermal stability, Nano-crystal

\section{1. 緒 言}

酸化チタン $\left(\mathrm{TiO}_{2}\right)$ は顔料や光触媒として用いられるだけ ではなく，優れた触媒担体であることが知られている1) 3)。 くに酸化チタンーバナジウム系触媒は，アンモニア脱硝用の工 業触媒として長年の実績がある。しかし，より厳しい窒素酸化 物排出基準に対応するため, 触媒の高性能化が求められてい る. 高性能化の最も有效な手段の一つとして, 担体である酸化 チタンの比表面積を大きくし，バナジウム種の活性点を増やす ことが举げられる。なた，触媒は高温で使用されるため，高温 時の担体酸化チタンの凝着（めるいは凝結）や比表面積の低下 を抑制する，つまり熱安定性を向上させることが必要である。

一般に沈殿法や加水分解法、ゾルーゲル法などを用いると大 きな比表面積を有する無定形の含水酸化物が得られる。これを 熱処理するとアナタース型酸化チタンが得られるがその結晶化 の際に比表面積が急激に低下する4) 7)，また，アナタースから ルチルへの相転移が $550^{\circ} \mathrm{C}$ 付近から始まる5),6)，以上のことか ら，バナジウム系脱硝触媒の高性能化を目指す場合，大きな比 表面積でかつ熱安定性に優れた酸化チタン担体を上記の手法で 得ることは難しいと思われる，一方，酸化チタンの相転移を抑 制するために修飾剤を添加する試みが行われており，酸化二才 ブ $\left(\mathrm{Nb}_{2} \mathrm{O}_{5}\right)^{8)}$ や, 硫酸イオン $\left(\mathrm{SO}_{4}{ }^{2-}\right)^{9)}$, ケイ素（シリカ,

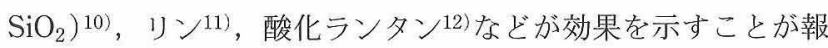
告されている。

Inoue ら ${ }^{13)}$ は，アルミニウムアルコキシドとオルトケイ酸工 チルの混合物をグリコール中で反応（グリコサーマル反応）さ せて得られた生成物を焼成することでシリカ修飾アルミナを調 製している，この試料ではアルミナ中にシリカが均一に高分散 されて扔り $\alpha$-アルミナへの相転移が抑制されるため, 高い熱 安定性が認められた13). 共沈法などの他の方法ではシリカの 分散が難しく，得られた試料の $\alpha$-アルミナへの相転移温度は

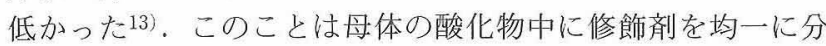

散させることが熱安定性を高めるためには重要であることを示 唆している.

著者は，高温高圧下，有機溶媒中における金属酸化物などの 無機化合物の合成を検討し，水を用いた系では見られない特徵 ある結果を得てきた ${ }^{14)}$ 19)，そのなかで，有機溶媒中に溶忛込 む少量の水を用いて，チタンアルコキシドを加水分解すると同 時に水熱結晶化させる手法 (HyCOM 法, hydorthermal crystallization in organic media) ヒより,アナタース型酸化チタ ンのナノ結晶が得られること，むた，これが高い熱安定性を示 すことを見いだした20). 酸化チタンの熱安定性を更に向上さ せるためには第 2 成分で修飾したナノ結晶性酸化チタンを合 成することが有效でめると考えられる。その祭，前述のように 第 2 成分を酸化チタン中に高分散させる必要がある。しか し， 2 種類の出発原料と水との反応性，たとえば加水分解速度 などが大きく異なる場合には系内に水が存在する HyCOM 法 を用いて修飾剂が高分散した酸化チタンを合成することは難し いと思われる。

本研究では, 水を用いない新規な手法, 高温·高圧下でチタ ンアルコキシドとリン酸エステルを有機溶媒中で共熱分解させ る手法により，リンが高分散した酸化チタンナノ結晶の合成を 試みた，得られた生成物の相転移挙動や熱安定性，リンの分散 状態について検討した。

\section{2. 実 験}

リン修飾酸化チタンの合成には，図１に示すようなオートク レーブを用いた。 チタンイソプロポキシド（関東化学，TIP） $25 \mathrm{~g}$ とリン酸トリエチル（関東化学, TEP）を所定のモル比 になるようにガラス容器中のトルエン（関東化学） $70 \mathrm{~cm}^{3}$ に 加えた。 ガラス容器とオートクレーブの壁面の間にもトルエン $25 \mathrm{~cm}^{3}$ 入れ, 系内を窒素で置換後, $2.5^{\circ} \mathrm{C} \cdot \mathrm{min}^{-1}$ の速度で 300 ${ }^{\circ} \mathrm{C}$ な゙昇温し，その温度で溶媒の自己発生圧（約 $10 \mathrm{MPa}$ )下 


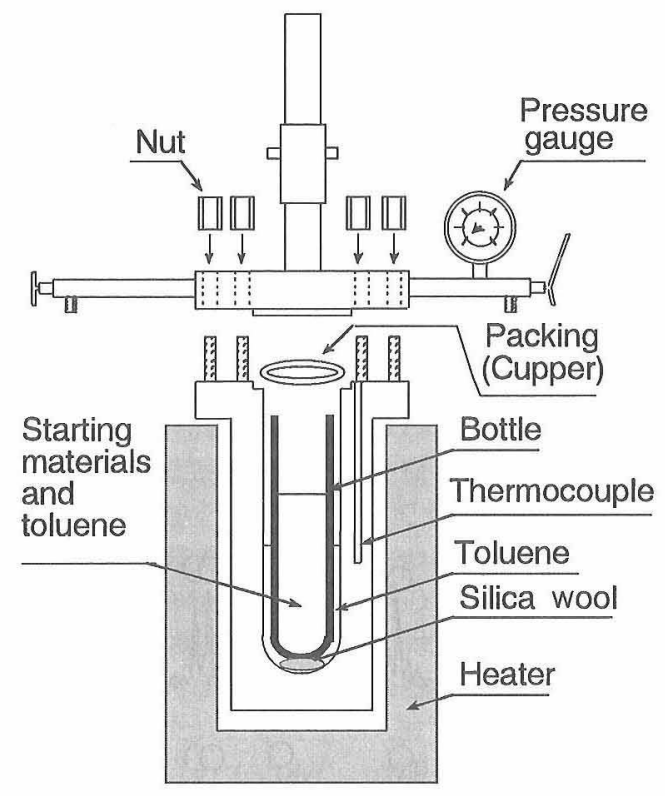

Fig. 1. Reaction apparatus.

で $2 \mathrm{~h}$ 保持した。得られた生成物をアセトンで繰り返し洗浄 後, 室温で風乾した. 以後, 生成物を PT $X$ ( $X$ は仕込灭 $\mathrm{Ti}$ ) $\mathrm{P}$ 比）で表す。たとえば，Ti/P比19の条件で得られた生成物 をPT19とする。

粉末 X線回折 (XRD) は $\mathrm{CuK} \alpha$ 線を用いて理学電機製 RINT 2500 で測定した。熱重量分析（TG）上示差熱分析 (DTA) は, 理学電機製 TG-8101を用いて, 空気䨌围気下 $\left(100 \mathrm{~cm}^{3} \cdot \mathrm{min}^{-1}\right)$ で測定した．X 線光電子分光 (XPS) 測定 は島津製作所製の ESCA-850で $\mathrm{Mg} \mathrm{K} \alpha(1253 \mathrm{eV})$ を用いて $\mathrm{C} 1 \mathrm{~s}=284.2 \mathrm{eV}$ 基準として測定した。透過型電子顕微鏡 (TEM) 観察は日本電子製 JEM-3010で加速電圧 $300 \mathrm{kV}$ で 行った. TEM の試料の調製は, 蒸留水中, 試料を超音波で分 散させた後，支持膜付き銅グリッドに固定した．試料の比表面 積の測定は BET一点法（窒素分圧0.3）で測定した．生成物 をマッフル焒（アドバンテック東洋KM160）中, $10^{\circ} \mathrm{C} \cdot \mathrm{min}^{-1}$ の速度で目的の温度末で昇温し, その温度で 1 h 保持後, 放冷 することで焼成試料を得た。

\section{3. 結果と考察}

3.1 熱分解法によるリン修飾酸化チタンの合成

種々な Ti/P 比の条件で得られた生成物の XRD パターンを 図 2 に示す.TEPが存在しないときはアナタース型酸化チタ ンが生成した $(\mathrm{PT} \infty)$. TEPが共存したときの結晶化生成物 はいずれもアナタース型酸化チタンのパターンを示したが，修 飾量の増加に伴いそのピークは弱くなり, リンがアナタースの 結晶化を阻害していると考えられる. リンが大量に存在する条 件で得られたPT1 は無定形であった. PT19の TEM 写真を 図 3 に示す. PT19は平均粒子径が $18 \mathrm{~nm}$ の十ノ粒子の凝集体 であることが分かった。この粒子径は XRD より求めた結晶子 径 $(19 \mathrm{~nm})$ とほぼ一致し，また，孤立粒子全体にアナタースの 101 面 $(0.3520 \mathrm{~nm})$ の格子像がはっきりと見られたことから， PT19はナノ結晶の集合体であるとことが明らかとなった。

PT19のTG-DTAの結果を図 4 示す. TG曲線においては

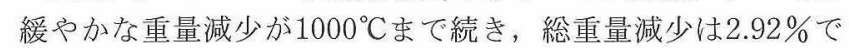
あった. DTA曲線には $300 \sim 400^{\circ} \mathrm{C}$ の範囲で小さくブロードな

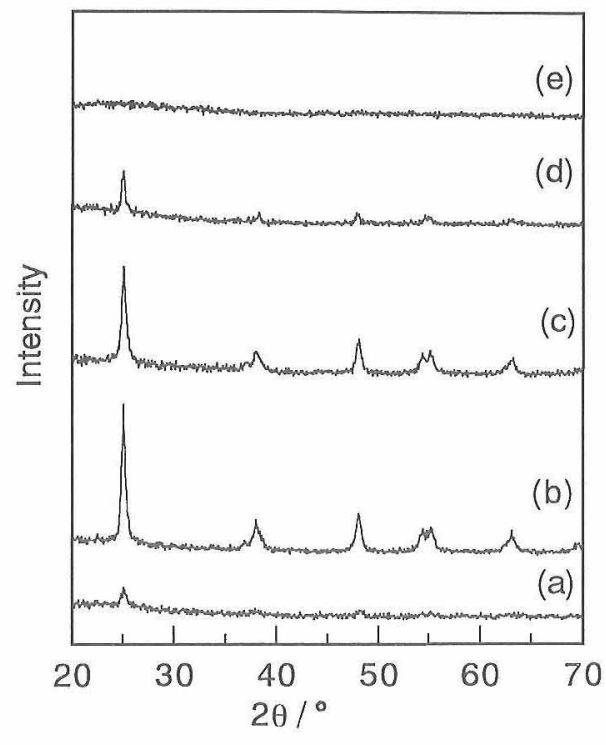

Fig. 2. XRD patterns of (a) PT $\infty$, (b) PT19, (c) PT9, (d) PT4 and (e) PT1.

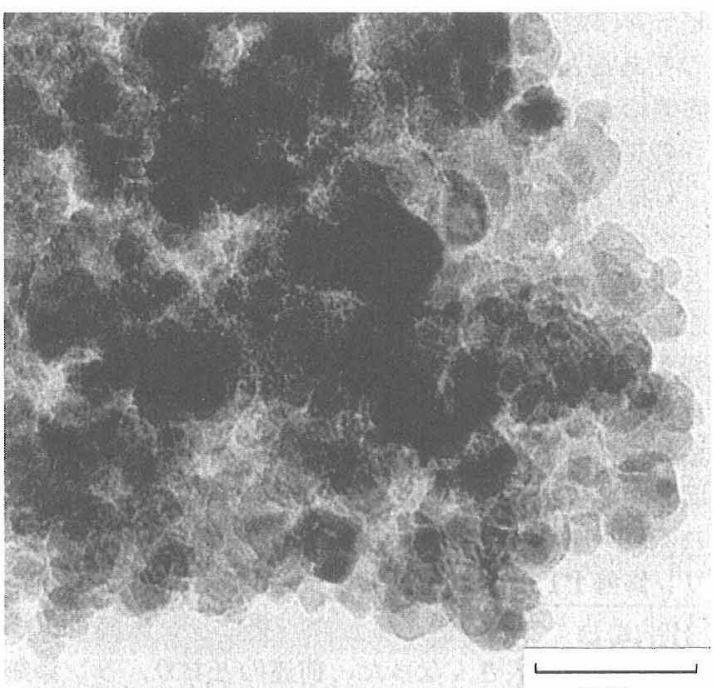

$50 \mathrm{~nm}$

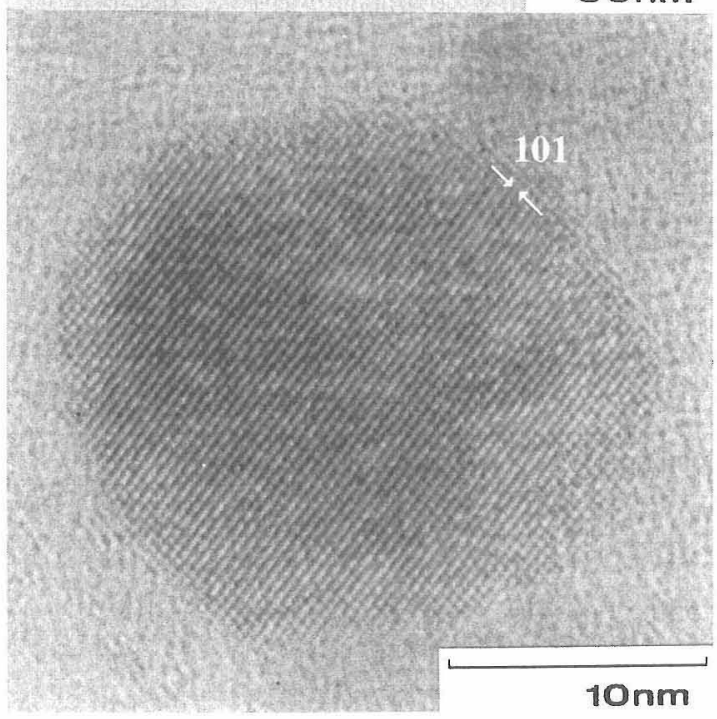

Fig. 3. TEM photographs of PT19. 


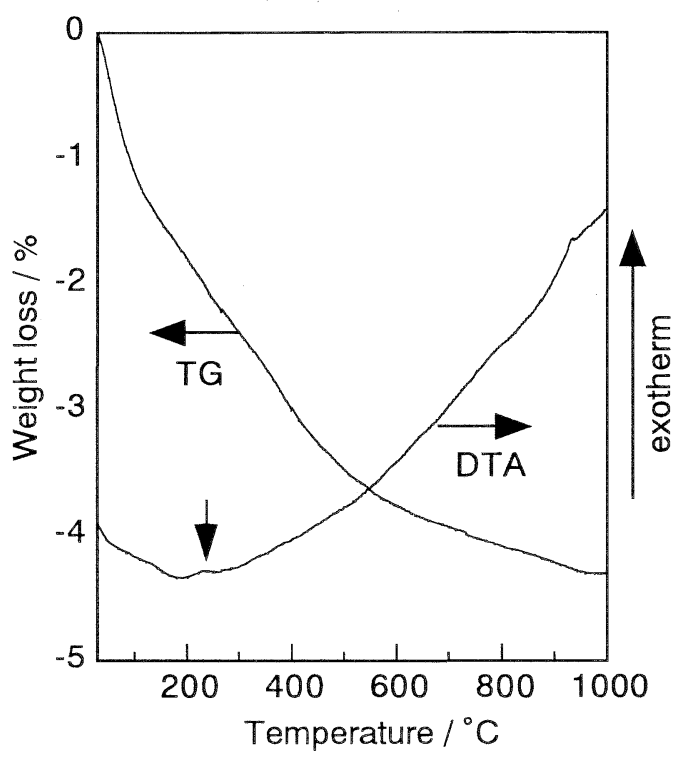

Fig. 4. TG-DTA curves of PT19.

発熱ピークと $932^{\circ} \mathrm{C} に$ 明瞭な発熱ピークが観察された。前者の 発熱ピークは溶媒であるトルエンや表面の有機残基の燃焼によ るものであると考えられる。なた，PT心に㧈いては，有機残 基の燃焼による発熱ピークは認められたが，アナタースからル チルへの相転移による明瞭なピークはみられなかった。 PT19

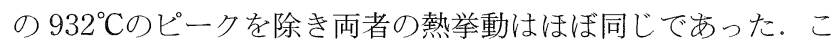
のピークは後述するように P-Ti 系の複合化合物（以後 PT 化 合物と略す）の結晶化によるものと考えられる. 有機残基の分 解後の高温まで続く緩やかな重量減少は表面水酸基の脱水や粒 子間脱水によるものと考えられる. その他の試料, PT9, PT4, PT1の総重量減少はそれぞれ5.6, 8.5, 9.3\%となり, リン修飾 量の増加に伴い増加する傾向が認められた。これについても反 応機構々関連づけて後述する。

それぞれの試料の比表面積を表 1 に示す. リン未修飾 PT $\infty$ 及びリン修飾 PT19 の比表面積はナノ粒子を反映してそれぞれ $85,83 \mathrm{~m}^{2} \cdot \mathrm{g}^{-1}$ と大きな值を示した. 更にリン修飾量を増加さ せると比表面積は大きくなった。前述のと抢り, リン修飾量が 増加すると, アナタースの結晶性が低下し, 無定形部分の割合 が増加したために比表面積が大きくなったと考えられる.

\section{2 焼成の影響}

PT 0 及び PT19をさまざまな温度で焼成して得られた試料 のXRD パターンを図 5 に示す。 PToを $700^{\circ} \mathrm{C} て ゙$ 焼成すると少 量のルチル相が生成し, $800^{\circ} \mathrm{C}$ 焼成後には完全にルチル相へ転 移した。一方, PT $19 を 800^{\circ} \mathrm{C}$ で焼成してもアナタース相が維

Table 1. BET Specific Surface Area of the Samples

\begin{tabular}{cccccr}
\hline Calcination & \multicolumn{5}{c}{ Specific surface area $/ \mathrm{m}^{2} \mathrm{~g}^{-1}$} \\
\cline { 2 - 6 } temp. $/{ }^{\circ} \mathrm{C}$ & PT $\infty$ & PT19 & PT9 & PT4 & PT1 \\
\hline--- & 85 & 83 & 91 & 118 & 199 \\
550 & 70 & 78 & 89 & 109 & 181 \\
700 & 26 & 68 & 72 & 57 & 4 \\
800 & 3 & 54 & 28 & 19 & $-\cdots$ \\
900 & & 22 & & & \\
\hline
\end{tabular}
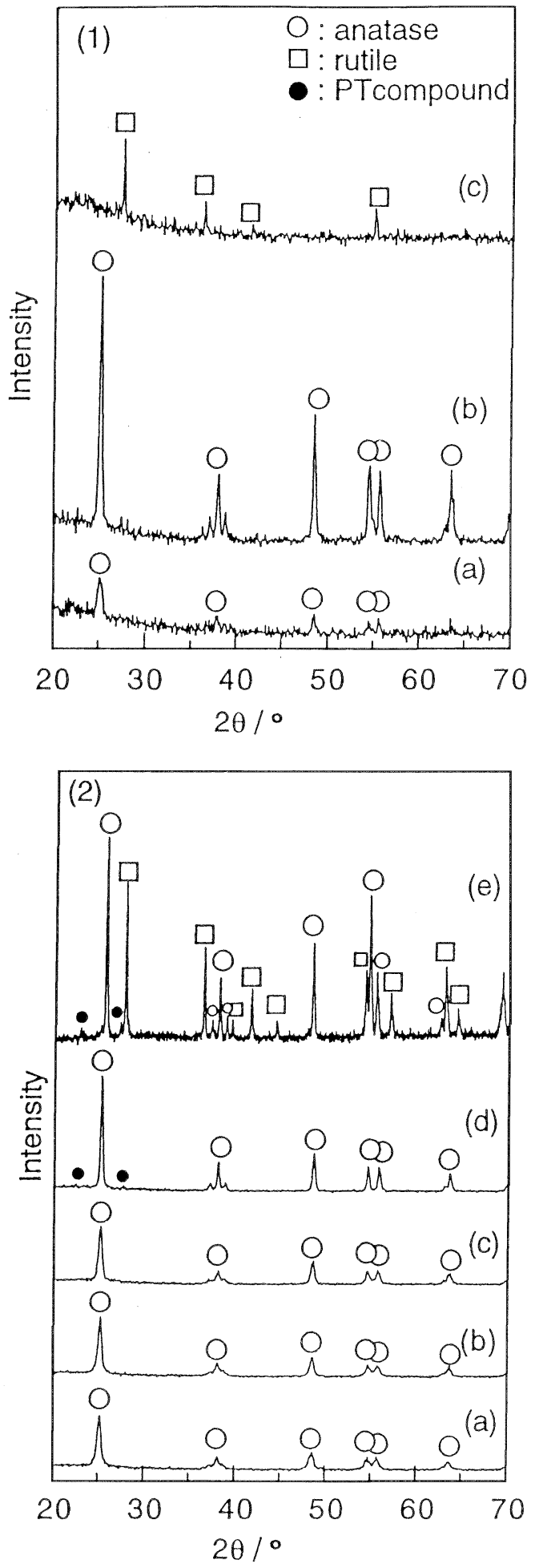

Fig. 5. XRD patterns of the samples obtained by calcination of (1) $\mathrm{PT} \infty$ and (2) $\mathrm{PT} 19$ at (a) $550^{\circ} \mathrm{C}$, (b) $700^{\circ} \mathrm{C}$, (c) $800^{\circ} \mathrm{C}$, (d) $900^{\circ} \mathrm{C}$ and (e) $1000^{\circ} \mathrm{C}$.

持され，ルチル相は全く見らなかった. Criado と Real'11) は市 販の結晶性酸化チタン（Degussa P-25）にリンを吸着させる と, 未処理のものに比べてルチルへの相転移温度が上昇するこ とを報告しており，本試料においても同様にリンの修飾効果が 見られた。更に温度を上げた $900^{\circ} \mathrm{C}$ 焼成後においてもアナター ス相が維持されていたが，極少量のPT 化合物と思われる相が 
生成した。したがって，PT19の熱分析（図 4）において観察 された $932^{\circ} \mathrm{C} の$ 発熱ピークはこのPT 化合物の結晶化によるも のと考えられる. $1000^{\circ} \mathrm{C}$ 焼成後，ルチルの生成が見られた が，いまだアナタースが優勢であった．生成物の焼成に伴う結 晶相の変化を表 2 によぬた。 PT9及び PT4に抢いては, $\mathrm{PT} 19$ より $100^{\circ} \mathrm{C}$ 低い温度で PT 化合物の生成が認められた。 た，無定形 PT1に拈いては $800^{\circ} \mathrm{C}$ 暁成後，アナタース及び PT 化合物がともに結晶化した。

次に，焼成に伴う物性の変化を調べた，PT心に抢けるアナ タースの結晶子径は焼成温度を上げていくと徐々に大きくな り，700 ${ }^{\circ}$ 榤成後は $29 \mathrm{~nm}$ と大きくなった（図 6)。これに刘 し，リン修飾PT 19 を $800^{\circ} \mathrm{C}$ 燒成しても，その結晶子径はほと んど変化せずリン修飾が酸化チタンの結晶成長を抑制すること が分かった。PT19の $800^{\circ} \mathrm{C}$ 焼成試料の TEM 写真(図 7 )には, 粒子の結晶成長や凝着は見られず，また，XRD から求めた結 晶子径 $(21 \mathrm{~nm})$ と TEMに見られる粒子の平均径 $(22 \mathrm{~nm})$ はよく対応していた。このことからリン修飾により酸化チタン 粒子の凝着も抑制されていることが明らかとなった。焼成に伴 う比表面積の変化（表 1）をみると, PT 後むでは比較的大きな值を維持していたが， $700^{\circ} \mathrm{C}$ 付近から急 激に低下しはじめた。一方, リン修飾PT190場合, $800^{\circ} \mathrm{C}$ 筧 成後も $54 \mathrm{~m}^{2} \cdot \mathrm{g}^{-1}$ ときわめて大きな值を示した．前述のように リン修飾試料は高温焼成後も小さい粒子径を維持しているため このような大きな比表面積を示したと結論できる. 更にPT19 を $900^{\circ} \mathrm{C}$ で焼成するとPT 化合物が生成し，アナタースの結晶 子径は37 nm と大きくなった。むた，TEM 観察から，粒子は 凝着により大きく成長する様子が認められた。これに対応し て，比表面積は $22 \mathrm{~m}^{2} \cdot \mathrm{g}^{-1}$ と低下した．チタンアルコキシドを 常圧下で加水分解すると大きな比表面積 $\left(452 \mathrm{~m}^{2} \cdot \mathrm{g}^{-1}\right)$ の無 定形含水酸化チタンが得られたが， $550^{\circ} \mathrm{C} て ゙$ 燒成するとアナ タースの結晶化・結晶成長が急激に進行し比表面積は著しく小 さくなった $\left(29 \mathrm{~m}^{2} \cdot \mathrm{g}^{-1}\right)$. PTळとの比較から結晶性の高いつ ナタースのナノ粒子を合成することが耐熱性向上に対して重要 であると考えられる. TEP を共存させて加水分解法で得られ た生成物（比表面積 $149 \mathrm{~m}^{2} \cdot \mathrm{g}^{-1}$ ) の場合も同様にアナタース の結晶化に伴い比表面積が急激に低下し（比表面積 $9 \mathrm{~m}^{2}$. $\left.\mathrm{g}^{-1}\right)$ ，リン修飾の効果はほとんどみられなかった。これらの 結果から，ナノ結晶性アナタースに対してリン修飾の効果が著 しく高いことが明らかになった。

\section{3 耐熱性に対するリン修飾量の影響}

種々なモル比で得られた試料に対する焼成温度の影響につい て検討した，PT9, PT4 $4700^{\circ} \mathrm{C}$ 暁成後もアナタ一ス相を維持 し，ルチル相の生成は見られなかった（表 2)，更に $800^{\circ} \mathrm{C} て ゙$ 焼

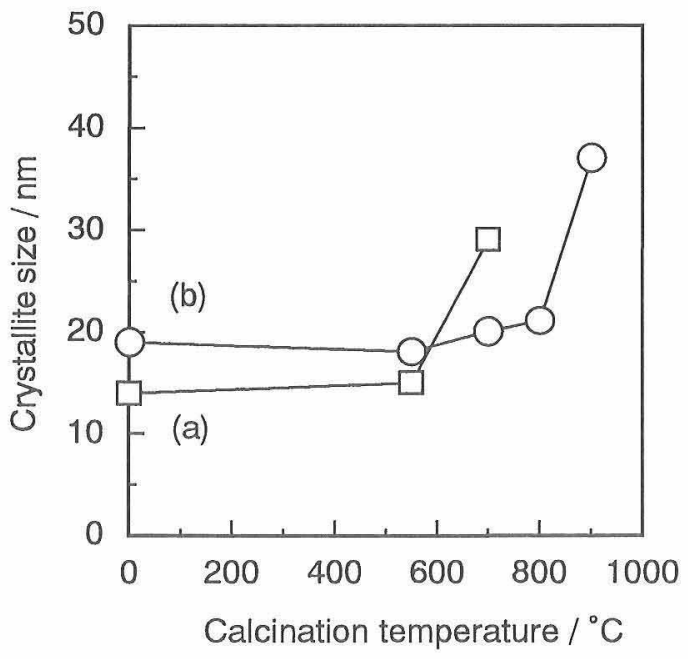

Fig. 6. Effect of calcination temperature on the crystallite size of anatase in (a) PT $\infty$ and (b) PT19.

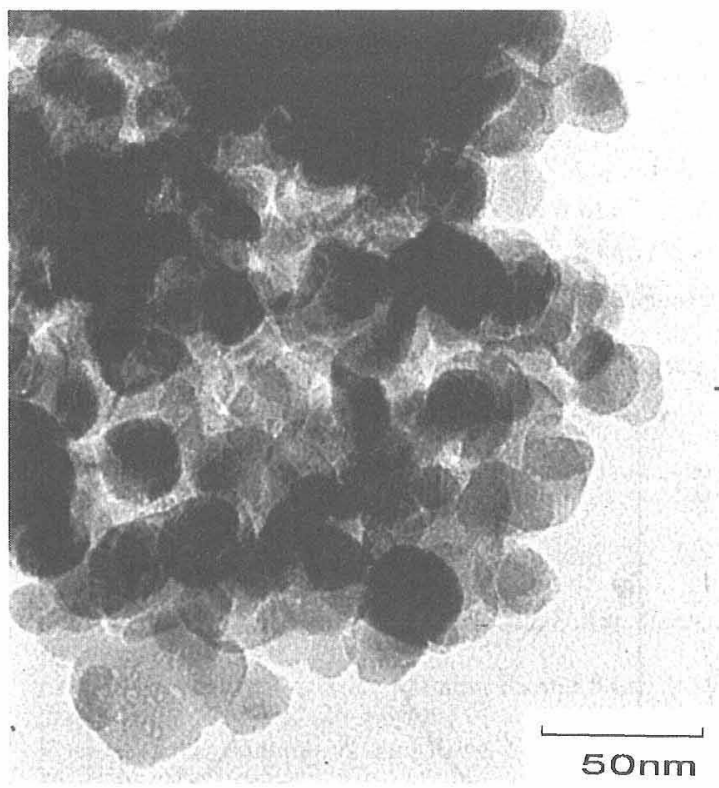

Fig. 7. TEM photograph of the sample obtained by calcination of PT19 at $800^{\circ} \mathrm{C}$.

成するとわずかに PT 化合物が生成した，PT1は700 ${ }^{\circ} \mathrm{C}$ 尭成後 も無定形であったが， $800^{\circ} \mathrm{C}$ に温度を上げるとアナタース相が

Table 2. Phase Transformation of the Samples

\begin{tabular}{cccccc}
\hline Calcination & \multicolumn{5}{c}{ Crystal phase } \\
\cline { 2 - 6 } temp. $/{ }^{\circ} \mathrm{C}$ & PT $\infty$ & PT19 & PT9 & PT4 & PT1 \\
\hline$\cdots--$ & A & A & A & A & amor. \\
550 & A & A & A & A & amor. \\
700 & A $\gg$ R & A & A & A & amor. \\
800 & R & A & A, U & A, U & A, U \\
900 & & A, U & & & \\
1000 & & A, U, R & & & \\
\hline
\end{tabular}

A: anatase, $\mathrm{R}$; rutile, $\mathrm{U}$ : unknown (P-Ti compound) 
結晶化するとともにPT 化合物の生成も認められた。一般に無 定形含水酸化チタンのアナタース相への結晶化温度は300〜 $450^{\circ} \mathrm{C}$ であるが, PT1の場合, リンが多量に存在するためにア ナタース相への結晶化が妨げられたものと考えられる。

焼成に伴う比表面積の変化を見ると（表 1), PT19が最も小 さく耐熱性が高く, リン修飾量が多いものほど比表面積の低下 が著しく耐熱性は低下した。 DTAで見られる PT 化合物の生 成温度は PT19が最も高く, PT9, PT4 でそれぞれ813, $809^{\circ} \mathrm{C}$ とPT19と比べて低くなった. 以上の結果から, 少量のリン修 飾によりアナタース相からルチル相への相転移が抑制され， $800^{\circ} \mathrm{C}$ 尭成後も大きな比表面積を維持するが，過㮃のリン修飾 試料ではむしろ高温焼成時に PT 化合物が生成するために耐熱 性は低下することが分かった。

\section{4 リン修飾酸化チタンのXPS 測定}

さまざまなモル比で得られた試料の表面状態をXPSにより 検討した。比較のために酸化チタン（触媒学会参照触媒 JRC一 TIO-2）々 $\mathrm{Na}_{2} \mathrm{HPO}_{4}$ (関東化学) ついて測定した。 いずれの 試料においても, Ti2p スペクトルのピーク值は $458.0 〜 458.3$ $\mathrm{eV}$ にみられ，比較試料の JRC-TIO-2 $(458.2 \mathrm{eV})$ とほとん どかわらなかった．一方, $\mathrm{P} 2 \mathrm{p}$ スペクトルのピーク值は 132.6 $\sim 132.9 \mathrm{eV}$ に見られ，比較試料 $\mathrm{Na}_{2} \mathrm{HPO}_{4}(135.5 \mathrm{eV})$ と大きく 異なった。このことから Tiに結合した $\mathrm{PO}_{4}$ 種の存在が示唆さ れる。O1s スペクトル（図 8 ）については，529.3 eVのピー クに加えて530.6 eVにショルダーピークが観察された. 前者 のピークは酸化チタンの $01 \mathrm{~s} の$ 位置 $(529.8 \mathrm{eV})$ とよく一致 したが，後者は $\mathrm{Na}_{2} \mathrm{HPO}_{4}$ の $\mathrm{O} 1 \mathrm{~s}$ の位置 $(533.3 \mathrm{eV})$ とはかな

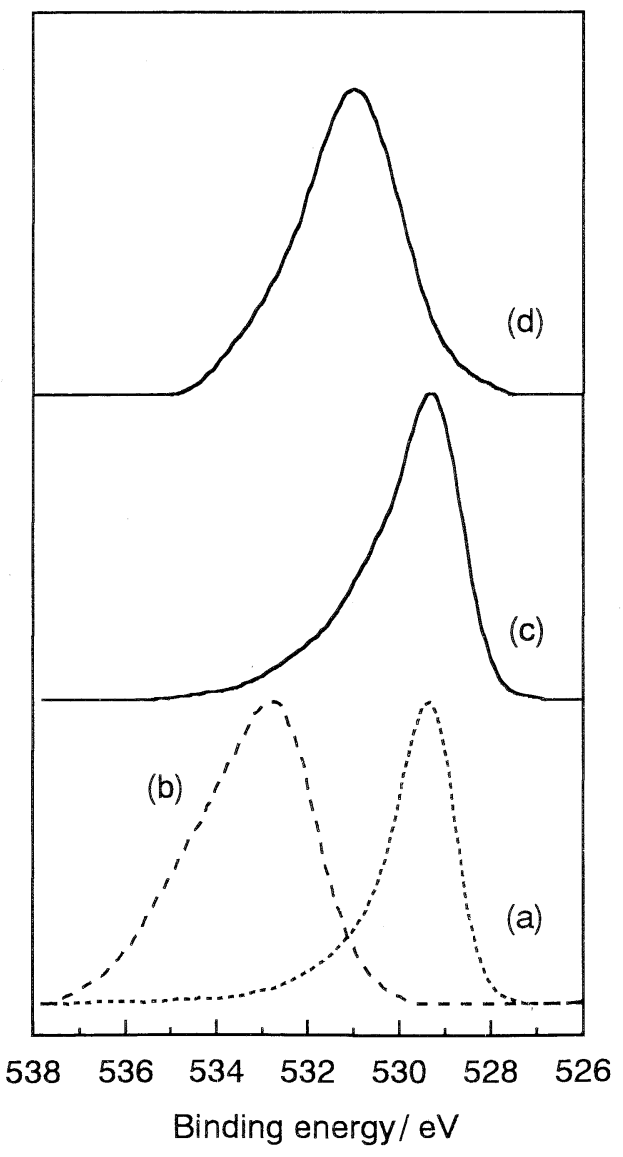

Fig. 8. O1s XPS spectra of (a) $\mathrm{TiO}_{2}$ (JRC-TIO-2), (b) $\mathrm{Na}_{2} \mathrm{HPO}_{4}$, (c) PT19 and (d) PT1.
り異なっていることより, チタンとリンに結合した酸素種によ るものと考えられる. 以上の結果から, PT19 中には Ti-O-Ti 結合と Ti-O-P 結合が存在すると考えられ, かつ, P-O-P 結 合は存在しない, あるいは，かなり少ないと考えられる. アナ タース構造に基づく $\mathrm{PT} 190$ 格子定数は $a_{0}=0.3796 \mathrm{~nm}, c_{0}=$ $0.9459 \mathrm{~nm}$ と求められ, とくに $c_{0}$ は文献值 $(0.9514 \mathrm{~nm})^{21)}$ と 比較するとかなり小さかった. 酸化チタンとシリカ（あるいは アルミナ）の固溶体の格子定数に関する研究において固溶量の 増加に伴い $c_{0}$ が小さくなることが報告されている22),23). した がって, 本手法で合成したPT19中にリンは酸化チタンに固溶 している，あるいは高分散していると結論した。 また，リン修 飾量を増加させると $01 \mathrm{~s}$ スペクトルにおいて, Ti-O-P 結合が Ti-O-Ti 結合より優勢になった。 これはリン修飾量の増加に 伴い酸化チタン表面のリン濃度も同様に高くなることに対応し ている、しかし，いずれの試料においても P-O-P 結合による ピークは明確には観察されずリンは高分散していることを示し ている。

$\mathrm{PT} 190800^{\circ} \mathrm{C}$ 焼成後の試料において, Ti2p スペクトルは変 化が見られず，O1s スペクトルには Ti-O-Ti 及び Ti-O-P ピークに加えて新しいショルダーピークが $533.1 \mathrm{eV} に$ 見られ

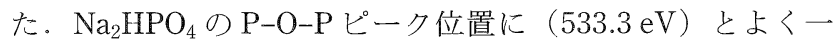
致することから恐らく $\mathrm{P}-\mathrm{O}-\mathrm{P}$ 結合によるものと思われる. 酸 化チタンに分散市るいは固溶していたリンが焼成に伴い粒子表 面に析出し, 表面のリン濃度が増加した結果, リンの縮合が進 行したと考えられる.

\section{5 リン修飾酸化チタンの生成機構と熱安定化機構}

次に本手法に抢ける TIP と TEP の共熱分解の反応機構を示 す (Scheme). 本反応条件下でTIP は熱分解しアナタース型 酸化チタンが得られた $(\mathrm{PT} \infty)$ 。この場合, TIP 中の $\mathrm{TiO}-\mathrm{C}$ 結合が開裂することで生成した Ti-O- 種が別の TIP を攻撃し て Ti-O-Ti 結合を生じ，アナタース構造を形成すると考えら れる。一方, TEPのみを同条件で加熱しても熱分解しなかっ た。したがって，TIP と TEP 共存下では，Ti-O-Ti 結合の形 成に加えて，Ti-O- が TEP を攻撃して Ti-O-P 結合を形成す る過程も同時に進行すると考えられる. TEP 自身は熱分解し ないため，P-O-P 結合の形成は不可能である。したがって， リンはTi-O-P 結合を介してアナタース骨格に取り込まれる 上考えられる. また，アナタース骨格に取り込まれず表面に存 在しているリン種は，リン 1 原子当たり一つあるいは二つの 未分解のエステル結合を有していると考えられる。熱分析にお いて観察された発熱を伴う重量減少はこれら残留有機物の燃焼 によるものと考えられる. リンの修飾量を増加させるとエステ ル結合を開裂させる攻撃種であるTIPのリンに対する割合が 減少し, 未開裂のエステル結合の数が多くなるため重量減少率 が増加すると考えられる。

酸化チタンの相転移抑制に対するリン11) あるいはケイ素 (シリカ) ${ }^{10)}$ 修飾の効果が報告されている. Criado とReal'11) は 酸化チタンに化学吸着したリンが酸化チタンの表面イオンの可 動性を妨げるために相転移を抑制すると考察しており，また， Suyama と $\mathrm{Kato}^{10)}$ は $\mathrm{TiO}_{2}-\mathrm{SiO}_{2}$ に扔いて修飾量が増加すると $\mathrm{TiO}_{2}$ 表面を $\mathrm{SiO}_{2}$ で覆うため $\mathrm{TiO}_{2}$ の結晶成長や相転移を阻害 することを報告している. また, アルミナの熱安定性向上のた めにシリカ修飾剤の添加が検討されており13),24) 28), 同様な機 構が提案されている.しかし, 常法では修飾剂を原子レベルで 分散させることは難しい. 近年, Inoue ら ${ }^{13)}$ は, グリコールを 溶媒に用いるグリコサーマル法によりケイ素（シリカ）が高分 散したシリカ修飾アルミナを合成し，これがきわめて高い熱安 


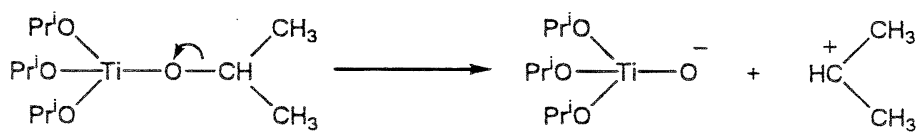

TIP

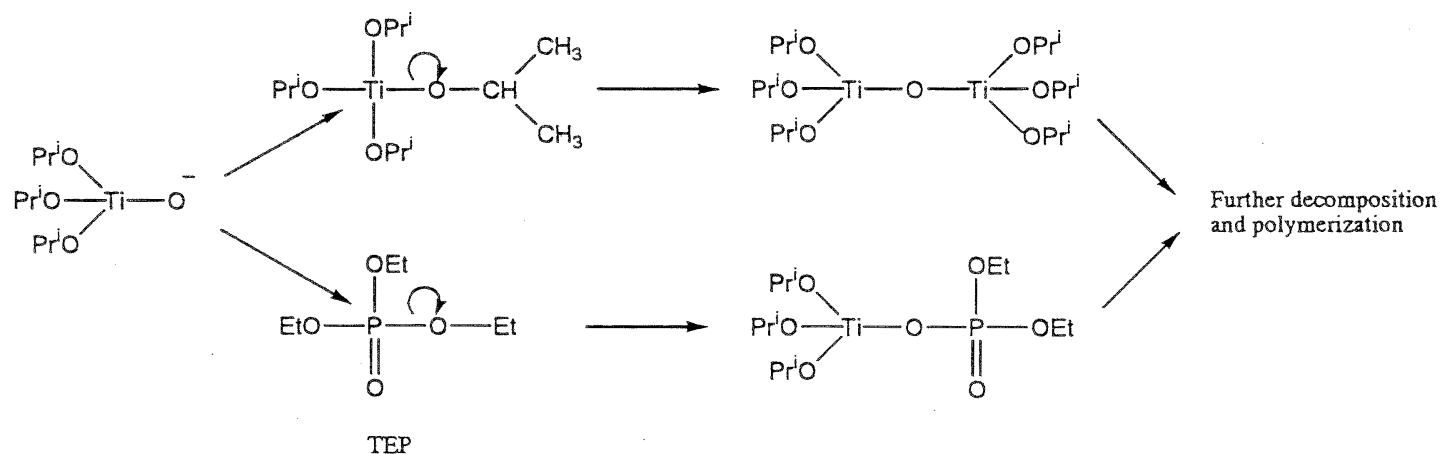

Scheme

定性を示すことを見いだしている。その安定化機構として高分 散したシリカがアルミナの相転移を抑制しているためである々 報告している．本手法により合成されたリン修飾酸化チタンの 場合，先述のように反応機構上，リンはアナタース中に高分散 されている。したがって，その高い熱安定性の大きな要因とし て, Inoue らが提案しているように結晶格子内に分散（あるい は固溶）したリンがアナタース相の相転移を抑制することが挙 げられる，また，リンは結晶内に分散しているのと同様に結晶 表面にも分散している。この表面分散リン種が結晶（粒子）の 凝着やルチルの核形成を抑制していることも考えられる.

\section{4. 結 論}

少量のリン酸エステルとチタンアルコキシドを有機溶媒中 $300^{\circ} \mathrm{C}$ で共熱分解させることによりリン修飾アナタース型酸化 チタンを得ることができた。この試料は $800^{\circ} \mathrm{C}$ 焼成後もアナ タース相を維持し, $54 \mathrm{~m}^{2} \cdot \mathrm{g}^{-1}$ というきわめて大きな比表面積 を示した。これは出発原料の熱分解過程で酸化チタン中に高分 散状態で取り込まれたリンが酸化チタンの結晶成長や凝着等を 抑制したためであると考えられる。高い耐熱性を得るためには 合成段階で酸化チタンが結晶化しており，後焼成時の結晶化に よる粒成成長や凝着を回避すること，及びリンが酸化チタン中 に高分散していることが重要であることが明らかとなった。 た，リンの修飾量は $10 \mathrm{~mol} \%$ 以下（Ti/P 比19程度）がよいこ とが分かった。

\section{文献}

1) Matsuda, S. and Kato, A., Appl. Catal., 8, 149-65 (1983).

2) Inomata, M., Miyamoto, A. and Murakami, Y., J. Chem. Soc. Chem. Commun., 1980, 233-34.

3) Luck, F. A., Bull. Soc. Chim. Belg., 100, 781-800 (1991)

4) Montoya, I. A., Viveros, T., Dominguez, J. M., Canales, L. A. and Schifter, I., Catal. Lett., 15, 207-17 (1992).

5) Ding, X.-Z., Qi, Z.-Z. and He, Y.-Z., J. Mater. Sci. Lett., 14, 21-22 (1995)

6) Ding, X.-Z., Liu, L., Ma, X., Qi, Z.-Z. and He, Y.-Z., J. Mater. Sci. Lett., 13, 462-64 (1994).
7) Anilkumar, G. M., Damodaran, A. D. and Warrier, K. G. K., "Catalyst Materials for High-Temperature Processes,"Ed. by Ramesh, K. S., Misono, M. and Gai, P. L., Am. Ceram. Soc., Westerville (1997) pp. 93-103.

8) Hishita, S., Takata, M. and Yanagida, H., J. Ceram. Soc. Japan (Yogyo-Kyokai-Shi), 86, 631-32 (1978).

9) Kurosaki, A. and Okazaki, S., J. Chem. Soc. Japan, 1976, 1816-21 [in Japanese].

10) Suyama, Y. and Kato, A., J. Ceram. Soc. Japan (Yogyo-KyokaiShi), 86, 119-25 (1978) [in Japanese].

11) Criado, J. and Real, C., J. Chem. Soc., Faraday Trans. 1, 79, 2765-71 (1983).

12) LeDuc, C. A., Campbell, J. M. and Rossin, J. A., Ind. Eng. Chem. Res., 35, 2473-76 (1996).

13) Inoue, M., Otsu, H., Kominami, H. and Inui, T., Ind. Eng. Chem. Res., 35, 295-306 (1996).

14) Kominami, H., Matsuo, K. and Kera, Y., J. Am. Ceram. Soc. 79, 2506-08 (1996).

15) Kominami, H., Onoue, S.-I., Matsuo, K. and Kera, Y., J. Am. Ceram. Soc., 82, 1937-40 (1999).

16) Kominami, H., Matsuo, K. and Kera, Y., J. Am. Ceram. Soc., 81, 3035-37 (1998).

17) Kominami, H., Onoue, S.-I., Nonaka, S. and Kera, Y., J. Ceram. Soc. Japan. 107, 682-85 (1999) [in Japanese].

18) Kominami, H., Kato, J.-I., Takada, Y., Doushi, Y., Ohtani, B., Nishimoto, S.-I., Inoue, M., Inui, T. and Kera, Y., Catal. Lett., 46, 235-40 (1997).

19) Kominami, H., Murakami, S., Kato, J.-I., Kera, Y., Inoue, M., Inui, T. and Ohtani, B., J. Mol. Catal. A, 144, 165-71 (1999).

20) Kominami, H., Kohno, M., Takada, Y., Inoue, M., Inui, T. and Kera, Y., Ind. Eng. Chem. Res., 38, 3925-31 (1999).

21) JCPDS Card No. 21-1272.

22) Yoshinaka, M., Hirota, K. and Yamaguchi, O., J. Am. Ceram. Soc., 80, 2749-53 (1997).

23) Yamaguchi, O. and Mukaida, Y., J. Am. Ceram. Soc., 72, 330-33 (1989)

24) Wakao, Y. and Hibino, T., Nagoya Kogyo Shikensho Hokoku, 11, 588-95 (1962) [in Japanese].

25) Espie, A. W. and Vickerman, J. C., J. Chem. Soc., Faraday Trans. 1, 80, 1903-13 (1984).

26) Stacey, M. H., Br. Ceram. Trans. J., 87, 168-72 (1988).

27) Yoldas, B. E., J. Mater. Sci., 11, 465-70 (1976).

28) Gani, M. S. J. and McPherson, R., J. Mater. Sci., 12, 999-1009 (1977). 